\title{
Pharmacological evaluation on antihypertensive activity of a novel AT1 angiotensin II receptor antagonist
}

\author{
Bei Tang ${ }^{1}$, Helin $\mathrm{Li}^{2}$, Ze Zhong ${ }^{1, *}$, Huiping $\mathrm{Wu}^{1}$, Hongwei Shen ${ }^{1}$, Jiayuan $\mathrm{Hu}^{1}$, \\ Jianping $\mathrm{Ma}^{1}$, Jinting $\mathrm{Wu}^{1}$ and Yuehui Wang ${ }^{2}$ \\ ${ }^{1}$ The First People's Hospital of Jiande City, The Second Affiliated Hospital, Zhejiang University School of Medicine, 311600 , China \\ ${ }^{2}$ Functional and Interactive Polymers, Institute of Technical and Macromolecular Chemistry, RWTH Aachen University, Worringerweg 1 , \\ 52074 Aachen, Germany
}

Hypertension is a major risk factor for human cardiovascular health, which can damage heart, brain, kidneys, etc. In this study we aimed to develop novel angiotensin II receptor blockers (ARBs) that prevent the increase of blood pressure for treatment of hypertension. (2-(4-((2-Amyl-5-nitro-1H-benzo[d]-imidazol-1yl) methyl)-1H-indol-1-yl) tetrazole; compound 1a) was one of the ARBs designed and synthesized. It was prepared and orally administered to spontaneous hypertensive rats to study the antihypertensive effects. The maximum reduction in blood pressure reached $50 \mathrm{mmHg}$ after dosing compound 1a for $5 \mathrm{~h}$. Acute toxicity test was carried out on healthy 4 week old 30 male and 30 female ICR mice and $L D_{50}$ for 1 a was found to be $2864.03 \mathrm{mg} / \mathrm{kg}$. High performance liquid chromatography was employed to determine the level of 1a plasma concentration at various time points after administration. The plasma concentration of 1a increased after $2 \mathrm{~h}$, declined gradually and was still detectable in the plasma after $72 \mathrm{~h}$. The drug distribution analysis of 1a was performed on healthy Wistar rats. It was present in the liver with the highest concentration, in kidney with a lower concentration, and in the spleen, lung, heart and brain with the lowest concentration. It displayed high affinity to AT1 receptor, and had an efficient and long-lasting effect in reducing blood pressure, which lasted for more than $12 \mathrm{~h}$. Due to its biological safety, 1a could be absorbed quickly, metabolized smoothly, and can be distributed in important organs. Therefore, 1 a could be considered as a suitable ARB candidate for further studies.

Keywords: Angiotensin II receptor blockers, antagonistic activity, antihypertension, pharmacological evaluation.

CARDIOVASCULAR and cerebrovascular diseases are regarded as the leading cause of death worldwide and hypertension is becoming one of the major risk factors among patients due to poor lifestyle. According to the diagnostic criteria of hypertension, 2002 National Nutrition

*For correspondence. (e-mail: hzzhongze@163.com) and Health Survey data, that is, systolic blood pressure (SBP) is greater than $140 \mathrm{mmHg}$ and/or diastolic blood pressure (DBP) is less than $90 \mathrm{mmHg}$, showed that the prevalence crude rate of hypertension accounted for $18.8 \%$ in China and was found to increase with each year $^{1}$. Although there are several drugs for treating high $\mathrm{BP}$, still one-third of the patients lack complete cure ${ }^{2,3}$. It is recommended that hypertension awareness and control can significantly reduce the mortality of cardiovascular and cerebrovascular diseases, and help improve the quality of life.

Angiotensin II receptor blockers (ARBs), which are novel hypertension drugs are gaining attention in patients with hypertension. ARBs play a significant role of AT1 receptor blocker, blocking the combination of Angiotensin II (Ang II) and AT1 receptor, and preventing increase in BP. In addition, ARBs have no effect on blocking AT2. Therefore, Ang II can bind AT2 receptor and lower $\mathrm{BP}^{4,5}$. "The Seventh Report of the Joint National Committee on Prevention, Detection, Evaluation and Treatment of High Blood Pressure' provides a new way for managing and preventing hypertension ${ }^{6-14}$. At the same time, adverse reactions arise from ARBs, such as cough and angioedema, through slightly lower than those in angiotensin-converting-enzyme inhibitor (ACEI) classes. If patients are unable to tolerate ACEI class of antihypertensive drugs, ARBs are recommended for use. On the other hand, it has been reported that ARBs can present hypotension in overweight patients ${ }^{15,16}$.

Sartans, a class of non-peptide drugs, are commonly used to treat hypertension after the application of ACEI and calcium antagonists ${ }^{17-19}$. Among these, losartan is now the most widely used antihypertensive agent due to its long-lasting effect, mild toxicity, less side effects and easy administration ${ }^{20,21}$. It can be used as an ideal drug in the treatment of hypertension and congestive heart failure. However, losartan has side effects such as headache, asthma, nausea, occasional high potassium and may also cause renal dysfunction in sensitive individuals and abnormal renal artery stenosis patients ${ }^{22}$. Losartan has also been reported to influence to a certain extent ${ }^{23,24}$. 


\section{RESEARCH ARTICLES}

The aim of the present study was to explore the synthesis of a novel type of ARBs, which has the advantages of losartan and also does not cause or reduce side effects of antihypertensive drugs. We synthesized compound 1a (2-(4-((2-amyl-5-nitro-1H-benzo[d]imidazol-1-yl) methyl)1H-indol-1-yl) tetrazole), and explored its antihypertensive effects through various experiments. In the AngII receptor binding experiments, 1a exhibited high affinity. In antihypertensive activity measurements, it had a better antihypertensive effect than losartan. It could reduce BP for more than $12 \mathrm{~h}$, and did not affect heart rate. Pharmacokinetic experiments showed that 1a can be absorbed quickly and metabolized smoothly. Therefore, it has good hypotensive effect. It is safe, long-lasting, and can be used as a antihypertensive medication.

\section{Materials and method}

Rotary evaporator (RE-3000A, Shanghai Yarong Instrument Company, Shanghai, China), gamma counter (SN682, Shanghai Hesuo Rihuan Photo Electronic Instrument Corporation, Shanghai, China), high performance liquid chromatography (HPLC; L-3000, Beijing Jingke Rida Technology Instrument Corporation, Beijing, China), tissue homogenate machine (PRO200, Shanghai Sustained High Biotechnology Limited Company, Shanghai, China) were employed in this study.

The chemical reagents used were 2-pentyl-5-nitro-1benzimidazole (ITC Chemical Industry Development Co. Ltd). $\mathrm{K}_{2} \mathrm{CO}_{3}, \mathrm{MgSO}_{4}, \mathrm{MeOH}, \mathrm{NaOH}$ (Sinopharm Chemical Reagent Co. Ltd), saturated salt water, ethyl acetate, dichloromethane (DCM), dimethylformamide (DMF; Shanghai Lingfeng Chemical Reagent Co Ltd). All the chemical reagents were of analytical grade and did not need to be purified. Losartan (Shanghai Zhongkang Weiye Biological Science and Technology Co Ltd $)^{125}$ I-AngII radioimmunoassay kit (Beijing North Institute of Biological Technology) were also used in the study.

\section{Synthesisof compound 1a}

A mixture of 2-butyl-5-nitro-1h-benzo[d]imidazole (500 mg, $2.28 \mathrm{mmol})$ and ((4-bromomethyl)-1H-indol-1yl)(phenyl) methanone $(765 \mathrm{mg}, 2.44 \mathrm{mmol})$ in $50 \mathrm{ml}$ of acetone was added to $\mathrm{K}_{2} \mathrm{CO}_{3}$ solution $(435 \mathrm{mg}$, $3.15 \mathrm{mmol})$. The mixture was stirred for $6 \mathrm{~h}$ at $60^{\circ} \mathrm{C}$. The remaining solution was diluted with water and extracted three times using $50 \mathrm{ml}$ of ethyl acetate. The organic layer was washed with $75 \mathrm{ml}$ of saturated brine and dried using $\mathrm{MgSO}_{4}$. After filtration and reduced pressure distillation, the solvent was removed to obtain a product in the first step. Product a $(158 \mathrm{mg}, 0.45 \mathrm{mmol})$ and $\mathrm{K}_{2} \mathrm{CO}_{3}$ were dissolved in $10 \mathrm{ml}$ of dimethyl formamide. Next, 2Fluorobenzene nitrile $(0.08 \mathrm{ml}, 0.08 \mathrm{mmol})$ was added to the mixture, followed by heating and refluxing under nitrogen atmosphere for $5 \mathrm{~h}$. The remaining liquid was diluted with water and extracted four times with $30 \mathrm{ml}$ of ethanol. The organic phase was washed three times with saturated sodium chloride solution and dried using $\mathrm{MgSO}_{4}$ to get product $\mathrm{b}$ in the second step. Product $\mathrm{b}$ (107 mg, $0.24 \mathrm{mmol}$ ) was dissolved in $10 \mathrm{ml}$ of $5 \mathrm{M}$ $\mathrm{NaOH}$ and $10 \mathrm{ml}$ of methanol. The reaction mixture was heated with continuous stirring for $8 \mathrm{~h}$ in a condenser. The $\mathrm{pH}$ value was carefully adjusted between 5 and 6 with hydrochloric acid aqueous solution $(6 \mathrm{M})$. The remaining liquid was extracted five times with $20 \mathrm{ml}$ of methylene chloride. The organic layer was washed two times with saturated brine and dried with $\mathrm{MgSO}_{4}$. The organic solvent was removed under reduced pressure. Compound 1a was prepared.

\section{Receptor binding experiment: cell culture}

The primary vascular smooth muscle cells (VSMCs) were obtained from thoracic aorta of SPF SD rats (Shanghai SLAC Laboratory Animal Co. Ltd). Cell growth was observed using an inverted microscope and the cells were identified by immune histochemical methods. In order to measure cell viability, the Trypan blue counting method was employed ${ }^{25}$. A $1 \mathrm{~mm} \times 1 \mathrm{~mm}$ tissue block was cut from the thoracic aorta and then transferred to a cell culture bottle. The cell culture medium containing $10 \%$ foetal bovine serum and $1 \%$ streptomycin and penicillin was added when the tissue adhered uniformly to a tissue culture plastic ware. Then the culture bottle was incubated at $37^{\circ} \mathrm{C}$ and $5 \%$ of $\mathrm{CO}_{2}$ environment for $3-5 \mathrm{~h}$. Cells grew and gradually covered the entire wall. All the cells were incubated at $37^{\circ} \mathrm{C}$, and $5 \%$ of $\mathrm{CO}_{2}$ environment for continuous culture.

\section{${ }^{125}$ I-Ang II receptor binding assay}

Three to six generations of VSMCs were used for binding experiments. Compound 1a and losartan were dissolved in DMSO and diluted to different concentrations with PBS before the experiments. ${ }^{125}$ I-Ang II (Beijing North Institute of Biological Technology, Beijing, China) was dissolved with PBS at $37^{\circ} \mathrm{C}$. VSMCs $\left(10^{6}\right.$ cells/well, $500 \mathrm{ml}$ ) were seeded into 24 -well plates and with $5 \%$ of $\mathrm{CO}_{2}$. After the cells adhered to the wall, they were washed and incubated in PBS containing $0.1 \mathrm{nM}{ }^{125} \mathrm{I}$-Ang II and compounds of different concentrations and then cultivated in $4^{\circ} \mathrm{C}$, for $150 \mathrm{~min}$. The final concentrations of the compound 1a was in the range $10^{-12}-10^{-6} \mathrm{M}$ and non-specific binding represented $5 \%-10 \%$ of total binding, which was measured in the presence of $1 \mu \mathrm{M}$ Ang II. The resulting VSMCs were washed thrice with PBS and digested for $10 \mathrm{~min}$ with $0.1 \mathrm{M} \mathrm{NaOH}$. The binding rate of the cells combined with ${ }^{125} \mathrm{I}$-Ang II was estimated using $\gamma$ counter. The $\mathrm{IC}_{50}$ and half inhibitory rates of $\mathbf{1 a}$ are calculated using the non-linear part of the competitive curve ${ }^{6}$. 


\section{Activity of blood pressure in vivo}

Compound 1a was dissolved in DMSO and oleic acid in the ratio $1: 4$. Next, 18 spontaneously hypertensive rats were selected randomly and divided into three groups, that is, blank control group, losartan group and compound 1a group with $1 \mathrm{ml}$ dose $(10 \mathrm{mg} / \mathrm{kg})$ in each rat. Noninvasive arteriacaudalis blood pressure measurement was used to measure BP in rats during the normal state before administration, and also at 1, 2, 3, 4, 5, 6, 7, 8, 9, 10, 12 and $24 \mathrm{~h}$ respectively. SBP, DBP and heart rate were recorded at every time point. Average blood pressure $(\mathrm{MBP})=(\mathrm{SBP}-\mathrm{DBP}) / 3+\mathrm{DBP}$.

\section{Acute toxicity test}

Acute toxicity test of $1 \mathrm{a}$ was measured in 60 normal ICR mice (30 male mice, 30 female mice, $20 \pm 2 \mathrm{~g}$, Chinese Academy of Sciences). They were randomly divided into six groups, with half the number of male mice and female mice in each group. The dosages for each group were $5949.9,4164.9,2915.5,2040.8,1428.6$ and $1000.0 \mathrm{mg} / \mathrm{kg}$ separately. The mice were dosed once per day. Survival rate was calculated after two weeks. The mortality within 14 days was analysed by logistic regression. $\mathrm{LD}_{50}$ values and $95 \%$ confidence interval were calculated using the fitting analysis. The physiological indicators of toxicity, including skin changes, flexibility, aggression and breathing exercises, were observed and systematically recorded. On the 15th day, the surviving mice were dissected and their organs were examined for pathological changes.

\section{Pharmacokinetic experiments}

The plasma concentration was detected in Wistar rats using HPLC. A high performance liquid chromatograph was used to detect the concentration of drugs in the blood plasma. The principal component of this system is equipped with a four-element liquid phase pump, including Alliance 2489 separation module, on-line degassing device, automatic sampler and $600 \mathrm{~nm}$ ultraviolet absorption detector. Instrumental control, data acquisition and data processing were carried out using Waters software. The flow rate was $0.8 \mathrm{ml} / \mathrm{min}$, and sample volume was $20 \mu \mathrm{l}$. The $\mathrm{C}_{18}$ reverse-phase column $(150 \mathrm{~mm} \times 4.6 \mathrm{~mm}$, $5 \mu \mathrm{m})$ was used for separation at room temperature. The mobile phase A was $0.1 \%$ formic acid solution containing $2 \mathrm{~mm}$ ammonium acetate (20\%), while mobile phase B was methanol $(80 \%)$. A standard curve for 1a was established $(1,5,10,50,100$ and $500 \mu \mathrm{g} / \mathrm{ml})$.

\section{Tissue distribution of drugs}

Tissue distribution studies were conducted in 66 Wistar rats (half of the male and female rats, $200 \pm 20 \mathrm{~g}$, Shang- hai SLAC Laboratory Animal Co Ltd). They were randomly divided into 11 groups, and dosage used was $10 \mathrm{mg} / \mathrm{kg}$. The rats were killed at $0.5,1,2,4,6,8,12,24$, 48 and $72 \mathrm{~h}$ separately. The heart, liver, spleen, lung, kidney and brain were removed and cleaned with physiological saline. Next, $0.2 \mathrm{~g}$ of tissue was immersed in $1 \mathrm{ml}$ saline for further experiments. A tissue homogenizer was used to homogenize the tissue into liquid. Then $3 \mathrm{ml}$ of methanol was added to deposit the protein, vortexed for $1 \mathrm{~min}$ and centrifuged for $20 \mathrm{~min}$ at $6000 \mathrm{rpm}$ at $4{ }^{\circ} \mathrm{C}$. The supernatant was collected for further experiments.

\section{Statistical analysis}

The results are shown as the average value \pm standard deviation and analysed by one-way ANOVA. The difference between the comparative groups was statistically significant when the $P$-value was less than 0.05 (ref. 26). The results of binding experiment and antihypertensive activity experiment were calculated using the nonlinear regression program (GraphPad Prism 5.0 software).

\section{Results and discussion}

\section{Characterization method of $\mathbf{1 a}$}

The resulting product was not optimized. The chemical composition of the compound was identified by ${ }^{1} \mathrm{H}$ NMR and ${ }^{13} \mathrm{C}$ NMR (Figure 1).

The total amount of the obtained final product, viz. 1a, was $83 \mathrm{mg}$; and the yield was $73.8 \%$, and the melting point was $189-193^{\circ} \mathrm{C} .{ }^{1} \mathrm{H}$ NMR $\left(400 \mathrm{MHz}\right.$, DMSO- $\left.d_{6}\right)$ : $8.53(\mathrm{~d}, J=8.53 \mathrm{~Hz}, 1 \mathrm{~h}), 8.12(\mathrm{dd}, J=8.9,2.2 \mathrm{~Hz}, 1 \mathrm{~h})$, 7.71 (d, $J=9.0 \mathrm{~Hz}, 1 \mathrm{~h}), 7.67$ (s, 1 h), 7.57, 7.51 (m, 1 h), $7.49(\mathrm{~d}, J=3.3 \mathrm{~Hz}, 1 \mathrm{~h}), 7.44(\mathrm{~d}, J=7.8 \mathrm{~Hz}, 1 \mathrm{~h}), 7.29$ (s, 1 h), 7.14 (d, $J=8.3 \mathrm{~Hz}, 1$ h), 7.01 (t, $J=7.8 \mathrm{~Hz}, 1 \mathrm{~h}$ ), $6.63(\mathrm{~d}, J=3.1 \mathrm{~Hz}, 1 \mathrm{H}), 6.39$ (d, $J=7.2 \mathrm{~Hz}, 1 \mathrm{H}), 5.90$ (s, $2 \mathrm{H}), 2.90(\mathrm{t}, J=7.5 \mathrm{~Hz}, 2 \mathrm{H}), 1.73(\mathrm{~m}, 2 \mathrm{H}), 1.34(\mathrm{~m}, 2 \mathrm{H})$, $0.84(\mathrm{t}, J=7.3 \mathrm{~Hz}, 3 \mathrm{H}) .{ }^{13} \mathrm{C}$ NMR $\left(101 \mathrm{MHz}\right.$, DMSO- $\left.d_{6}\right)$ : $169.01,160.58,143.09,142.03,140.71,137.09,136.03$, $135.75,130.98,130.65,129.20,128.25,128.17,126.51$, $122.37,118.12,117.14,115.13,111.20,110.58,100.88$, $45.56,29.06,27.06,22.22,14.12$.

\section{${ }^{125}$ I-Ang II radio ligand receptor binding experiment}

Compound 1a and losartan are competitive with regard to binding with ${ }^{125}$ I-Ang II (Figure 2 and Table 1). The 1a had a higher affinity to bind with AT1 receptor (1a: $\mathrm{IC}_{50}=4.05 \pm 2.11 \mathrm{nM}, \quad \mathrm{Ki}=2.93 \pm 1.53 \mathrm{nM} ; \quad$ losartan: $\mathrm{IC}_{50}=12.23 \pm 3.42 \mathrm{nM}, \mathrm{Ki}=8.86 \pm 2.49 \mathrm{nM}$ ). The radioactive receptor binding experiment showed that $\mathbf{1 a}$ had specific binding capacity to the AT1 receptor. 


\section{Antihypertensive activity experiment}

Antihypertensive activity experimental results revealed that (Figure 3), at the dose of $10 \mathrm{mg} / \mathrm{kg}$, compound 1a showed good activity, began to reduce BP after $1 \mathrm{~h}$ and reached maximum hypotensive value at $50 \mathrm{mmHg}$ in $5 \mathrm{~h}$ (Figure 3). The activity persisted for more than $12 \mathrm{~h}$. The antihypertensive effect was obvious until $24 \mathrm{~h}$. However, at the dose of $10 \mathrm{mg} / \mathrm{kg}$, losartan reached maximum hypotensive value at $45 \mathrm{mmHg}$ in $3 \mathrm{~h}$ and antihypertensive activity in $12 \mathrm{~h}$. The pressure drop in losartan for $24 \mathrm{~h}$ was less than that in compound 1a. In addition, 1a did not affect the heart rate of rats. Compound 1a was more effective in lowering BP at the same dose, and was more stable and long-lasting.

\section{Acute toxicity test}

In the acute toxicity test, $\mathrm{LD}_{50}$ value of $\mathbf{1 a}$ was $2897.34 \mathrm{mg} / \mathrm{kg}$, and $95 \%$ confidence interval was 2466.84-3418.04 mg/kg (Table 2). No abnormalities were found in the ICR mice, but individual mice died at

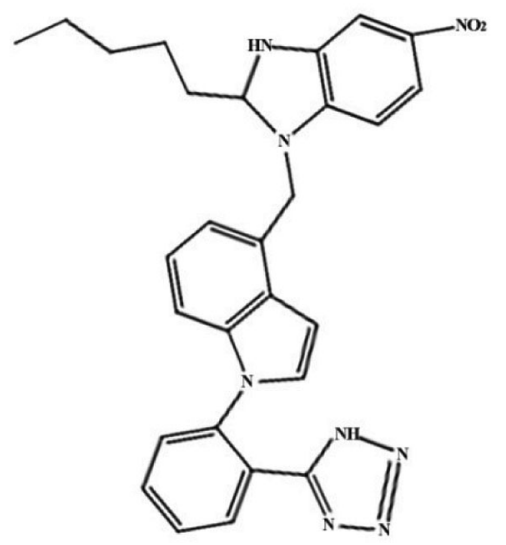

Figure 1. Chemical structure of compound 1a.

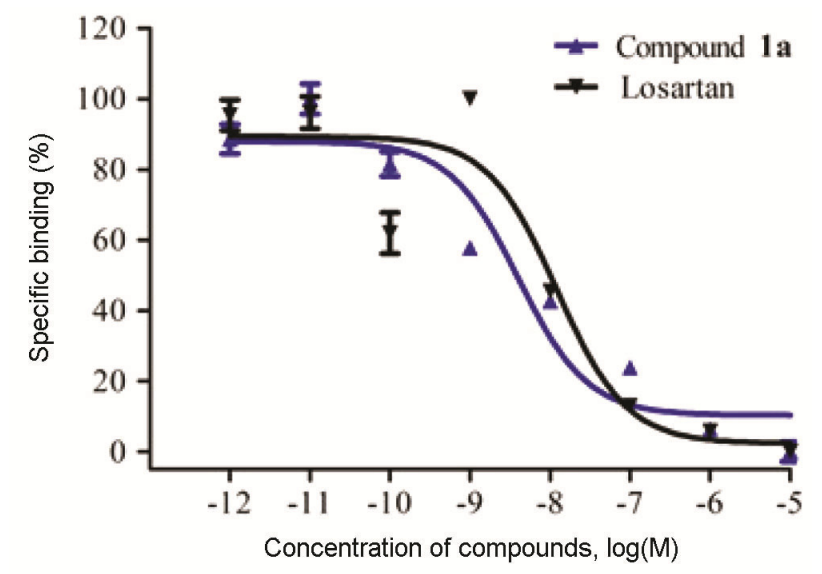

Figure 2. Inhibitory effects of compounds $\mathbf{1 a}$ and losartan $\left(10^{-5}\right.$ $10^{-12} \mathrm{M}$ ) on specific binding of ${ }^{125} \mathrm{I}-\mathrm{Ang}$ II to AT1 receptors in vascular smooth muscle cells the highest dose. The weight of mice did not change significantly after two weeks. The mice did not show obvious attack behaviours, indicating that 1a has low acute toxicity and high biosafety.

\section{Blood concentration experiment}

GraphPad Prism software, DAS 2.0 was used to estimate the pharmacokinetic parameters. Figure 4 shows average blood concentration versus time curve. After dosing

Table 1. $\mathrm{IC}_{50}$ and $\mathrm{Ki}$ values of the tested compound $\mathbf{1 a}$ and losartan

\begin{tabular}{lcc}
\hline Drugs & $\mathrm{IC}_{50} \pm \mathrm{SEM}(\mathrm{nM})$ & $\mathrm{Ki}(\mathrm{nM})$ \\
\hline Compound 1a & $4.05 \pm 2.11$ & $2.93 \pm 1.53$ \\
Losartan & $12.23 \pm 3.42$ & $8.86 \pm 2.49$ \\
\hline
\end{tabular}

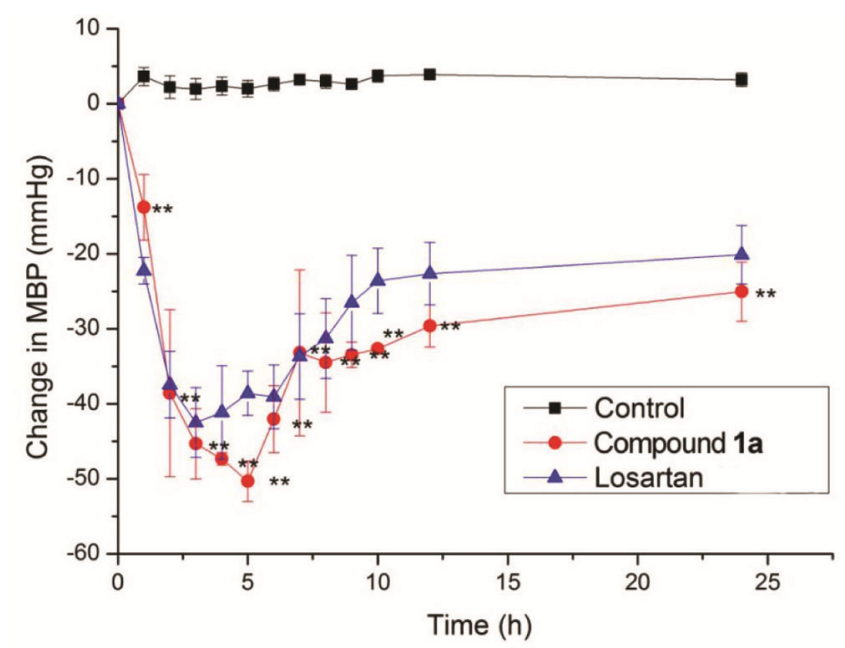

Figure 3. Effects of compound 1a $(10 \mathrm{mg} / \mathrm{kg})$ and losartan $(10 \mathrm{mg} / \mathrm{kg})$ on mean blood pressure (MBP) in SHRs. $* * *$ indicate significant difference from negative control, $P<0.05$ and $P<0.01$ respectively.

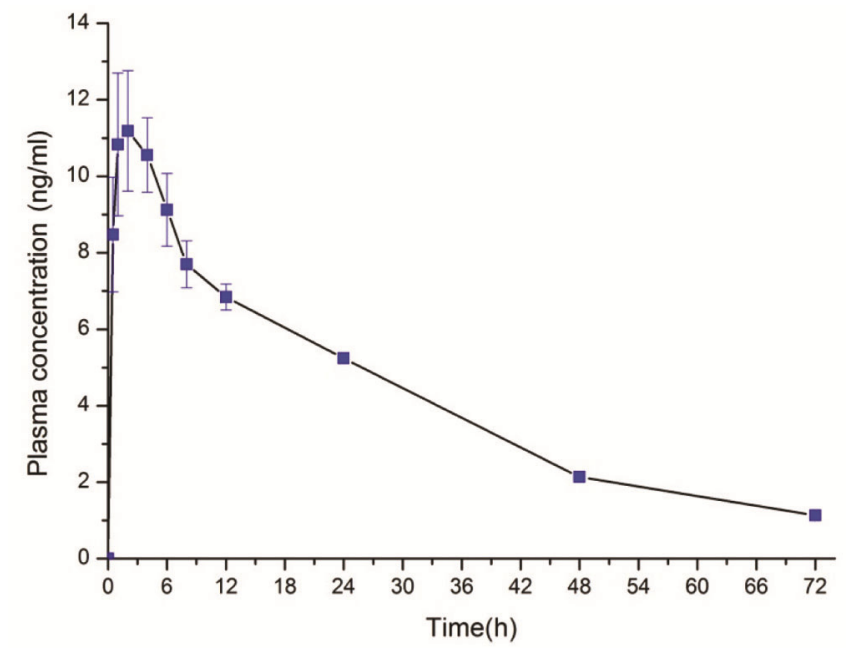

Figure 4. Plasma concentration of compound 1a $(10 \mathrm{mg} / \mathrm{kg})$ observed in rats by signal oral administration $(n=6)$. 
Table 2. Lethal dose $\left(\mathrm{LD}_{50}\right)$ of compound 1a determined by acute toxicity test $(n=10)$

\begin{tabular}{lccc}
\hline Dose $(\mathrm{mg} / \mathrm{kg})$ & $\log ($ dose $)$ & Mortality $(\%)$ & LD $_{50}$ and 95\% confidence interval \\
\hline 1000 & 3 & 0 & 2897.34 \\
1428.57 & 3.08 & 9 & $(2466.84-3418.04)$ \\
2040.82 & 3.25 & 28 & \\
2915.45 & 3.32 & 56 & \\
4164.93 & 3.57 & 84 & \\
5949.90 & 3.62 & 98 & \\
\hline
\end{tabular}

Table 3. Pharmacokinetic parameters of compound 1a $(10 \mathrm{mg} / \mathrm{kg})$ in tissues of Wistar rats observed by signal oral administration $(n=6)$

\begin{tabular}{|c|c|c|c|c|c|c|}
\hline Parameter & Heart & Liver & Spleen & Lung & Kidney & Brain \\
\hline$T_{\max }(\mathrm{h})$ & $0.4 \pm 0.31$ & $0.4 \pm 0.22$ & $3.8 \pm 0.40$ & $0.9 \pm 0.27$ & $0.49 \pm 0.14$ & $1.8 \pm 0.52$ \\
\hline$C_{\max }(\mathrm{ng} / \mathrm{g})$ & $8.41 \pm 0.43$ & $49.67 \pm 0.85$ & $13.73 \pm 0.14$ & $9.23 \pm 0.61$ & $20.38 \pm 0.38$ & $5.7 \pm 0.52$ \\
\hline $\operatorname{Ke}\left(h^{-1}\right)$ & $0.052 \pm 0.01$ & $0.06 \pm 0.03$ & $0.072 \pm 0.01$ & $0.062 \pm 0.04$ & $0.05 \pm 0.006$ & $0.042 \pm 0.01$ \\
\hline$T_{1 / 2}(\mathrm{~h})$ & $9.01 \pm 0.83$ & $10.74 \pm 0.06$ & $8.82 \pm 0.04$ & $12.53 \pm 2.05$ & $15.92 \pm 0.06$ & $16.5 \pm 0.01$ \\
\hline $\operatorname{AUC}_{0-72}(\mathrm{ng} / \mathrm{g} / \mathrm{h})$ & $199.037 \pm 0.68$ & $273.03 \pm 2.01$ & $283.28 \pm 0.81$ & $215.93 \pm 7.92$ & $201.93 \pm 7.82$ & $124.92 \pm 2.71$ \\
\hline
\end{tabular}

The parameters time to reach peak drug concentration $\left(T_{\max }\right)$, peak drug concentration $\left(C_{\max }\right)$, elimination rate constant $(\mathrm{Ke})$, mean apparent elimination half-life $\left(T_{1 / 2}\right)$ and concentration-time curve (AUC) was used.

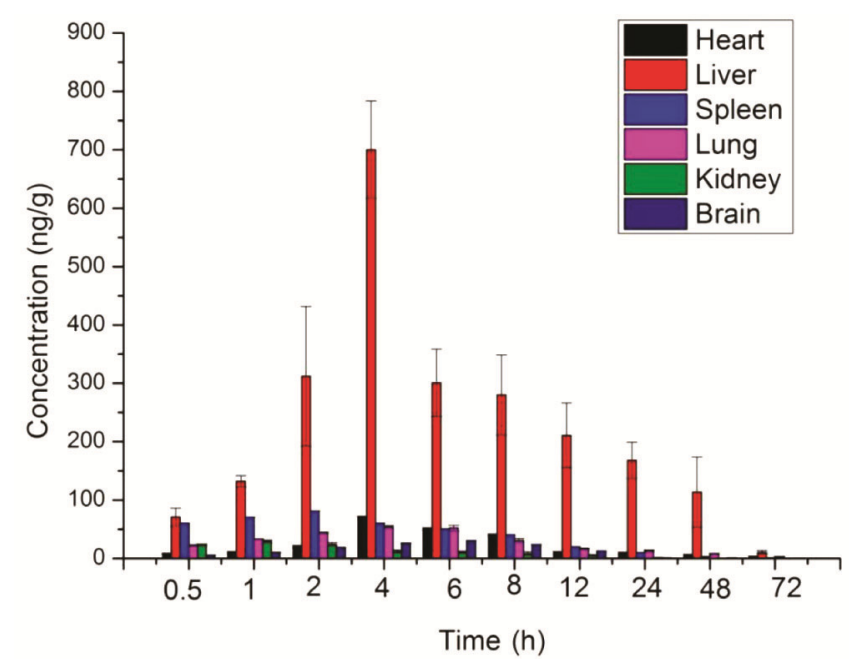

Figure 5. Tissue concentration of compound $\mathbf{1 a}(10 \mathrm{mg} / \mathrm{kg})$ in heart liver, spleen, lung, kidney and brain observed by a signal oral administration $(n=6)$.

$10 \mathrm{mg} / \mathrm{kg}$ of $\mathbf{1 a}$ for $2 \mathrm{~h}$, the serum concentration of Wistar rats approached the peak level. Thereafter, the blood concentration gradually decreased and presence of drug could still be detected after $72 \mathrm{~h}$. The results showed that 1a can be absorbed quickly and metabolized slowly in the body.

\section{Tissue distribution experiment}

The main parameters of each organization were shown in Figure 5 and Table 3. Compound 1a in the liver showed the highest concentration, followed by that in the kidney, spleen, lung, heart and brain. The lowest drug concentration was in brain tissue. Compound 1a is mainly metabo- lized by the liver. The drug residue could be observed even after $72 \mathrm{~h}$.

\section{Conclusion}

In this study, a novel type of angiotensin II receptor antagonist, 1a has been synthesized as an antihypertensive compound. Experiments were conducted to verify the antagonistic activity of $\mathbf{1 a}$ at the cellular level of AT1 receptor. The hypotensive effect of $\mathbf{1 a}$ in animals was verified by oral administration of spontaneous hypertensive rats. Acute toxicity experiments showed that 1a had a good biological safety. Results of the pharmacokinetic experiments showed that $\mathbf{1}$ a can be uniformly distributed in the body.

In conclusion, 1a for AT1 receptor has excellent antagonist effects. In addition, it can reduce BP quickly and smoothly. The antihypertensive activity lasted for more than $12 \mathrm{~h}$. Compound 1a can be absorbed quickly in the body and also can be distributed to the main tissues; so it plays a protective role to the heart, brain, kidney and other vital organs. Therefore, $\mathbf{1 a}$ is a novel potential drug for treating hypertension.

1. Ferrario, C. M., The remin-angiotensin system-importance in physiology and pathology. J. Cardiovasc. Pharmacol., 1990, 15, S1-S5.

2. Hallberg, I., Ranerup, A. and Kjellgren, K., Supporting the selfmanagement of hypertension: patients' experiences of using a mobile phone-based system. J. Hum. Hypertens, 2016, 30, 141146.

3. Li, X. et al., An rgd-modified hollow silica@au core/shell nanoplatform for tumor combination therapy. Acta Biomater., 2017, 62, $273-283$.

4. Munoz-Durango, N. et al., Role of the rennin-angiotensinaldosterone system beyond blood pressure regulation: molecular 
and cellular mechanisms involved in end-organ damage during arterial hypertension. Int. J. Mol. Sci., 2016, 17(7), 797.

5. Li, X., Yang, M., Shi, X., Chu, X., Chen, L., Wu, Q. and Wang, $Y$., Effect of the intramolecular hydrogen bond on the spectral and optical properties in chitosan oligosaccharide. Physica E, 2015, 69, 237-242.

6. Williamson, J. D. et al., Intensive vs standard blood pressure control and cardiovascular disease outcomes in adults aged $\geq 75$ years a randomized clinical trial. J. Am. Med. Assoc., 2016, 315, 26732682.

7. Storch, U., Blodow, S., Gudermann, T. and Schnitzler, M. M. Y., Cysteinyl leukotriene 1 receptors as novel mechanosensors mediating myogenic tone together with angiotensin ii type 1 receptors - brief report. Arterioscler, Thromb, Vasc. Biol., 2015, 35, 121-126.

8. Lyseng W., Olmesartan medoxomil/amlodipine/hydrochlorothiazide $20 \mathrm{mg} / 5 \mathrm{mg} / 12.5 \mathrm{mg}$ fixed-dose combination in hypertension: a profile of its use. Drugs Ther. Perspect., 2018, 34, $1-7$.

9. Ji, Y. H., Di, W. Y., Yang, Q. H., Lu, Z. H., Cai, W. M. and Wu, J. Q., Inhibition of autophagy increases proliferation inhibition and apoptosis induced by the pi3k/mtor inhibitor NVP-BEZ235 in breast cancer cells. Clin. Lab., 2015, 61, 1043-1051.

10. Santos, R. A. S. et al., The ACE2/angiotensin-(1-7)/MAS axis of the rennin-angiotensin system: focus on angiotensin-(1-7) Physiol. Rev., 2018, 98, 505-553.

11. Nie, Y. Y. et al., Synthesis and biological evaluation of novel potent angiotensin ii receptor antagonists with anti-hypertension effect. Bioorg. Med. Chem., 2012, 20, 2747-2761.

12. Uemura, H. et al., Angiotensin II receptor blocker shows antiproliferative activity in prostate cancer cells: a possibility of tyrosine kinase inhibitor of growth factor. Mol. Cancer Ther., 2003, 2, $1139-1147$

13. Li, X., Xing, L., Zheng, K., Wei, P., Du, L., Shen, M. and Shi, X., Formation of gold nanostar-coated hollow mesoporous silica for tumor multimodality imaging and photothermal therapy. ACS Appl. Mater Interf., 2017, 9, 5817-5827.

14. Wang, S. et al., Bottom-up synthesis of $\mathrm{WS}_{2}$ nanosheets with synchronous surface modification for imaging guided tumor regression. Acta Biomater., 2017, 58, 442-454.

15. Salvetti, G. et al., Chronic renin-angiotensin system (RAS) blockade may not induce hypotension during anaesthesia for bariatric surgery. Obes. Surg., 2016, 26, 1303-1307.

16. Yang, H., Zhao, J., Wu, C., Ye, C., Zou, D. and Wang, S., Facile synthesis of colloidal stable $\mathrm{MOS}_{2}$ nanoparticles for combined tumor therapy. Chem. Eng. J., 2018, 351, 548-558.

17. Ettehad, D. et al., Blood pressure lowering for prevention of cardiovascular disease and death: a systematic review and metaanalysis. Eur. Heart J., 2016, 37, 639-639.
18. Li, X., Yang, M., Ye, Z., Chen, L., Xu, C. and Chu, X., DFT research on the IR spectrum of glycine-tryptophan oligopeptides chain. Acta Phys. Sin., 2013, 62, 156103.

19. Zhao, J. et al., Outside-in synthesis of mesoporous sili$\mathrm{ca} /$ molybdenum disulfide nanoparticles for antitumor application. Chem. Eng. J., 2018, 351, 157-168.

20. Han, X. et al., Synthesis and biological evaluation of novel 2,3dihydrochromeno 3,4-d imidazol-4(1h)-one derivatives as potent anticancer cell proliferation and migration agents. Eur. J. Med. Chem., 2016, 114, 232-243.

21. Li, X., Yu, S., Yang, M., Xu, C., Wang, Y. and Chen, L., Electronic structure analysis of glycine oligopeptides and glycinetryptophan oligopeptides. Phys. E, 2014, 57, 63-68.

22. Bavishi, C., Bangalore, S. and Messerli, F. H., Outcomes of intensive blood pressure lowering in older hypertensive patients. J. Am. Coll. Cardiol., 2017, 69, 486-493.

23. Raimondi, S., Botteri, E., Munzone, E., Cipolla, C., Rotmensz, N., DeCensi, A. and Gandini, S., Use of beta-blockers, angiotensinconverting enzyme inhibitors and angiotensin receptor blockers and breast cancer survival: systematic review and meta-analysis. Int. J. Cancer, 2016, 139, 212-219.

24. Melville, J. M. and Hultstrom, M., Losartan may reduce the effect of fluid resuscitation following faemorrhage in rats. FASEB J., 2016, 30, 1217.12 .

25. Corry, D. B., Eslami, P., Yamamoto, K., Nyby, M. D., Makino, H. and Tuck, M. L., Uric acid stimulates vascular smooth muscle cell proliferation and oxidative stress via the vascular reninangiotensin system. J. Hypertens, 2008, 26, 269-275.

26. Li, X., Xiong, Z., Xu, X., Luo, Y., Peng, C., Shen, M. and Shi, X., ${ }^{99 \mathrm{~m}} \mathrm{Tc}$-labeled multifunctional low-generation dendrimer-entrapped gold nanoparticles for targeted SPECT/CT dual-mode imaging of tumors. ACS Appl. Mater. Interf., 2016, 8, 19883-19891.

ACKNOWLEDGEMENTS. Bei Tang and Helin Li contributed equally to this work. Bei Tang, Helin Li and Ze Zhong designed the idea of this study. Bei Tang and Helin Li were involved in the synthesis and characterization of all materials. Bei Tang, Helin Li, Ze Zhong and Yuehui Wang prepared and co-wrote the manuscript. Bei Tang, Huiping Wu, Hongwei Shen, Jiayuan Hu performed the cell experiments. Helin Li, Jianping Ma, Jinting Wu and Yuehui Wang conduced all animal experiments. Bei Tang and Helin Li analysed all data and collected all figures. The manuscript was discussed and commented by all authors. This research was financially supported by the China Scholarship Council and Medical Health Science and Technology Project of Zhejiang Provincial Health Commission (2018KY150), China.

Received 3 October 2018; revised accepted 28 March 2019

doi: $10.18520 / \mathrm{cs} / \mathrm{v} 116 / 112 / 1987-1992$ 